\title{
Транснаціональний бізнес і проблеми глобального управління
}

\author{
C.A. KBITKA \\ Аніпропетровський регіональний інститут Аержавного управління \\ Національної акалемії Аержавного управління при Презилентові України, \\ м. Аніпропетровськ, Україна, E-mail: skvitka@i.ua
}

\section{Авторське резюме}

У статті розглядаються питання впливу глобалізації на діяльність держав. Однією з головних рушійних сил глобальних змін є транснаціональні компанії, які мають значні ресурси для впливу на національні уряди. Швидкими темпами змінюється роль національних держав. Класичні функції державного управліня зменшуються і видозмінюються, набирають іншого змісту такі поняття, як суверенітет, демократія, громадянське суспільство. У сучасному світі вони мають розглядатись як аспекти глобального управління і несуть у собі риси наднаціональних явищ.

Зміна ролі держави в епоху глобалізації ставить політичну еліту світу перед необхідністю усвідомлення нових реалій, визначення вектора майбутнього світового розвитку. Епоха національних держав закінчується і вже сьогодні слід починати думати не тільки про економічну, але й про політичну інтеграцію. I мова йде не лише про перебудову державного контролю і його пристосування до процесів глобалізації, а й про докорінні зміни у державному управлінні взагалі.

Ключові слова: глобалізація, транснаціональна компанія, плюралістична модель, корпоративістська модель, мережна модель, євроінтеграція.

(C) C.A. Квітка, 2015 


\title{
Transnational business and problems of global governance
}

\author{
S.A. KVITKA \\ Dnepropetrovsk regional institute of public administration, the National \\ academy of public administration, office of the President of Ukraine, \\ Dnipropetrovsk, Ukraine, E-mail: skvitka@i.va
}

\begin{abstract}
The article examines the impact of globalization on the activities of states. One of the main driving forces of global change is a multinational company with significant resources to influence national governments. Rapidly changing role of the nation state. The classic functions of managing the reduced and modi-fied, gaining other content concepts such as sovereignty, democracy and civil society. In today's world they are seen as aspects of global governance and carry features supranational phenomena.

The changing role of the state in the era of globalization has become the political elite of world awareness of the necessity of new realities determine the vector of the future global development. The era of nation states ends and today should begin to think about not only economic, but also political integration. And it's not only the restructuring of state control and its adaptation to globalization processes, but also about fundamental changes in governance in general.

Keywords: globalization, multinational company, pluralistic model, corporatism model, network model, european integration.
\end{abstract}

Постановка проблеми. Перші наслідки вільного функціонування фінансових ринків на початку XXI ст. у світових масштабах виявилися далеко не обнадійливими.

Фінансовий крах 2008 року хворобливо позначився на економіці практично всіх країн світу, примусив задуматись над необхідністю створення не тільки національних, але й наднаціональних міжнародних систем економічного регулювання.

Оскільки роль національних держав слабшає або просто змінюється, то хто здатен замінити їx, аби стабілізувати економічні й суспільні процеси в масштабі всього світу? Як створити «концерн держав", здатних успішно виконувати не тільки чисто політичні, але й соціальноекономічні функції? Поки що проблема взаємовідносин бізнесу й політики на глобальному рівні лишається невирішуваною, і дискусія засвідчує, що не тільки на практиці, але і в теорії однозначних відповідей на ці питання немає.

Зміна ролі держави в епоху глобалізації ставить політичну еліту світу перед необхідністю усвідомлення нових реалій, визначення вектора майбутнього світового розвитку. Епоха національних держав закінчується і вже сьогодні слід починати думати не тільки про економічну, але й про політичну інтеграцію. I мова йде не лише про перебудову державного контролю і його пристосування до процесів глобалізації, а й про докорінні зміни у державному управлінні взагалі.

Аналіз публікацій $\mathbf{i}$ досліджень. Тематика глобального управління у співвідношенні до діяльності національних держав є предметом обговорення вже кілька десятиліть, власне кажучи, з самого початку вивчення феномена глобалізації. Можна згадати в цьому плані i ідеї створення Сполучених Штатів Європи на початку $\mathrm{XX}$ ст.

3 початком нового століття наукові дискусії навколо практики глобалізації та загострення відносин між державами та їх об'єднаннями стали більш актуальними і активними. I хоча їх основними учасниками є зарубіжні фахівці, такі як К.Браун, Дж.Маклін, Дж.Сакс, П.Херст, Г.Томпсон, Д.Месснер, К.Омає, Ф.Шміттер та інші, свій вклад у розробку цієї теми вносять і вітчизняні вчені. До таких можна віднесті О.Білоруса, М.Шепелєва, В.Сергеєва, Т.Мусієнко та інш.

Метою дослідження $є$ визначен- 
ня ролі транснаціональних компаній в управлінні світовим порядком в умовах глобалізації, їх участі у процесі глобальної перебудови, яка поза іншим веде до зменшення ролі національних держав та зміни парадигми державного управління взагалі.

Виклад основного матеріалу. Одним з основних протиріч сучасної епохи є протиріччя між посиленою потребою у загальносвітовій економіці і пануванням національно-державної форми господарювання. Погляди на способи зняття цього протиріччя різноманітні, але видається, що їх можна звести до чотирьох основних концепцій.

1. Концепція створення єдиної світової економіки і єдиного світу шляхом розвитку, а потім і об'єднання континентальних економічних i фінансових союзів, регіональних валют і континентальних політичних конфедерацій. Приклади для наслідування - ЄС і НАФТА, євро і долар. Розширення ЄС на Схід i перетворення НАФТА в єдину Американську зону вільної торгівлі супроводжуються створенням і зміцненням аналогічних угруповань і конфедерацій на інших континентах (наприклад, ACEAH, СНД, певний варіант економічного союзу в Північно-Східній Азії). Вірогідно, що на наступному етапі відбудеться інтеграційна стиковка континентальних конфедерацій: приміром, об'єднання СС і НАФТА в «Новий Трансатлантичний Ринок». Взагалі, на завершальному етапі прогнозується можливе злиття всіх континентальних конфедерацій в єдиний світ з єдиною економікою.

2. Найбільш радикальні пропагандисти американської економічної й суспільної моделі пропонують поширити господарську практику, валюту, законодавство і економічні інститути США на решту світу. Країни, які відкинуть нові умови, виявляться ізольованими від світової економіки і зв'язки з ними будуть зведені до мінімуму. Подібна модель не допускає негайного загального політичного об'єднання і залишає без уваги низку істотних питань, зокрема такі: чи будуть громадяни інших країн-учасників господарської системи мати право обирати американського президента і амери- канських законодавців, і якщо так, то з якого моменту.

3. Помірні прихильники глобалізації пропонують не забігати наперед, а виходити 3 існуючої дійсності і просувати глобалізацію поступово, лібералізуючи економічну i фінансову діяльність, розширюючи сферу відповідальності таких міжнародних організацій, як СОТ, МВФ і т.ін.

4. Концепція створення єдиного світового економічного правопорядку і розвитку на цій основі інтернаціональних інститутів, що дозволять проводити скоординовану світову соціально-економічну й фінансову політику. Питання про єдиний світ (у політичному сенсі) відсувається на потім, коли воно буде вирішено природним способом - шляхом поступового перетворення економічної інтеграції на політичну.

На практиці глобалізація тією чи іншою мірою відбувається по всіх перерахованих варіантах.

У сьогоднішньому світі принципово змінюється становище національних господарств як складових глобальної економічної системи і відповідно змінюються принципи встановлення і підтримки владних відносин між ними. «Силові» технології окремих держав уже не зв'язані ні із завоюванням територій, ні із прямим підпорядкуванням економічного простору супротивника. Вони націлені на нав'язування світовому оточенню своєї політичної волі й бачення соціально-економічної перспективи, на встановлення й підтримку бажаної форми світогосподарських зв'язків, на зміцнення або підрив певної системи соціально-економічних орієнтацій, тобто ідеології. Зіткнення стилів і форм господарювання, суперництво різних центрів світового розвитку врешті-решт має привести до вироблення якихось спільних норм і інститутів, що їх приймають, хоч і вимушено, всі учасники світового ринку. При цьому соціально-економічна конвергенція, посилювана повсюдною інформатизацією, сприяє уніфікації певних правил гри.

Можна погодитись з тим, що світова владна система координат поєднує нові центри сили із провідними персонажа- 
ми колишньої національно-державної системи, чиї реальні кордони в економічному універсумі вже зараз помітно відрізняються від звично чітких адміністративно-державних розмежувальних ліній, плавно трансформуючись у повзучий суверенітет зон національних інтересів і регіональної безпеки, що множаться по світу. У дуалістичній конструкції глобального всесвіту сполучаються, таким чином, два різні покоління владних суб'єктів - національні держави й різноманітні співтовариства-інтегрії [4] .

Глобалізація як система соціально-економічних відносин пов'язана 3 формуванням нових інститутів, які порізному співвідносяться 3 інституціональною структурою національного господарства, а отже, можуть мати місце різні траєкторії розвитку тієї чи іншої національної економіки. Процес перетворення і становлення нових глобальних інститутів є одночасно і природним i штучним. Імпортування глобальних соціально-економічних інститутів на національний рівень може викликати неоднозначні наслідки для інновацій: їх нейтралізацію, посилення, ослаблення й появу утворень, які або не планувалися, або яких не було раніше. Вже існуюче інституціональне середовище, норми, правила, організації національної держави можуть вирішально вплинути на ефективність нових інститутів, результативність і стійкість реформ. Крім цього, не слід забувати, що коли створюються нові структури, існує велика вірогідність невідповідності між декларованими цілями й реальними результатами.

Сучасному світові властива множинність рівнів і типів управління, яка відмінна і від моделей прийняття рішень міжнародними організаціями, і від простого диктату світового ринку. П.Херст і Г.Томпсон звертають увагу на те, що глобальне управління (governance) вбирає в себе всі наявні інститути і практичні функції: суспільні й приватні, державні i недержавні, національні й інтернаціональні; але національна держава як i раніше відіграє постійну і важливу роль сполучної ланки між діючими особами світової політики. Воно усуває розбіжності між ними, тому що має право де- легувати частину своїх функцій як міжнародному співтовариству (нагору), так i субнаціональним структурам (униз).

На думку цих вчених управління можливе на п'ятьох рівнях - від міжнародного до локально-регіонального - за допомогою:

1) дотримання міждержавних угод, особливо між країнами Європи та Північної Америки;

2) зусиль значного числа держав, які створюють міжнародні регулюючі організації типу СОТ або ГАТТ;

3) регіональних торгово-економічних асоціацій і союзів на зразок СС і НАФТА;

4) використання національних важелів і інститутів типу Асоціації Ренд (REND) у CШA;

5) проведення внутрідержавної регіональної політики для розвитку місцевих промислових центрів.

Така система управління, на їх думку, відповідає інтересам великого й малого бізнесу, що активно входить на світові ринки, де їм над усе потрібні стабільність та безпека [10].

Поєднати всі ці рівні здатна національна держава, тому що лише вона в тій або іншій формі присутня на кожному з них. У схемі глобального управління національна держава має стояти у центрі світових зв'язків і бути осередком відносин між усіма акторами міжнародного співтовариства: ООН і ї̈ різними установами, регіональними союзами, субнаціональними (локальними) органами, багатонаціональними концернами, банками, неурядовими організаціями, засобами масової інформації, різними групами інтересів, науковими центрами і т.ін. Їхні скоординовані зусилля мали б бути спрямовані на розв'язання чотирьох завдань управління в процесі глобалізації:

- визначення рамок світового порядку, в якому міжнародний бізнес не «приватизував» би політику;

- більш ефективне, ніж досі, реагування на глобальні виклики (забруднення навколишнього середовища, масові міграції, торгівля зброєю);

- формування глобальної правової державності на основі західних традицій правової держави;

- використання принципів управлін- 
ня при вирішенні національними державами регіональних і локальних проблем.

Однак національні держави, які повинні були б виконувати ключові функції при втіленні такого роду концепцій у життя, зустрічаються 3 логікою й інтересами капіталу, які можуть в одних випадках збігатися з демократично прийнятими політичними рішеннями, а в інших - суперечити їм.

Резонно виникає питання - якщо обсяг продажів п'яти найбільших світових корпорацій перевершує ВВП усіх держав Близького, Середнього Сходу і Північної Африки, то чи можна регулювати протиріччя між цими глобальними акторами, виходячи з політичного ідеалізму? I наскільки реально сформувати міждержавний «світовий концерн», який враховував би інтереси не тільки великих, але й малих країн?

Не викликає сумнівів факт, що головним суб'єктом глобалізації в сучасному світі виступають транснаціональні корпорації (ТНК). 500 найбільших ТНК контролюють 25\% усього валового внутрішнього продукту (ВВП) на Землі, на їхню долю припадає до $90 \%$ усіх прямих іноземних інвестицій у світі, вони володіють 80\% патентів і ліцензій на новітні технології. ТНК сьогодні - це близько 60 тис. основних (материнських) компаній і понад 500 тис. їх зарубіжних філій і афінованих (залежних) компаній по всьому світу. Роль ТНК у формуванні вузлових, визначальних тенденцій у розвитку сучасної світової економіки важко переоцінити. Будучи дійсно транснаціональними центрами рішень і дій, вони роблять значний вплив на світову економіку.

Завдяки своїм рішенням в сфері капіталовкладень і вибору місць розміщення виробництва ТНК відіграють важливу роль у розподілі світового виробничого потенціалу. Їх вплив на міжнародну торгівлю є пропорційним їхній участі в цій торгівлі. За деякими оцінками, ТНК здійснюють понад половини світового зовнішньоторговельного обороту. Утворюючи єдину мережу, транснаціональний капітал володіє однією третиною всіх виробничих фондів і виробляє майже половину загальнопланетарного продукту.

Масштаби їх міжнародних фінансо- вих операцій забезпечують їм привілейоване становище в якості позичальників або вкладників на ринку валют. ТНК контролюють до 90\% вивезення капіталу. Сукупні валютні резерви транснаціональних компаній у 5-6 разів перевершують резерви центральних банків усіх країн світу.

Розширюючи свою транснаціональну діяльність, вони створюють економічні передумови для організації міжнародного виробництва з єдиним ринковим та інформаційним простором і міжнародного ринку капіталів, робочої сили, науково-технічних, консультаційних та інших послуг. Борючись за ринки збуту в глобальному масштабі, ТНК підвищують рівень конкуренції, що викликає потребу в постійних інноваціях, зміні технологій i прискоренні науково-технічного прогресу. Сприяючи обороту капіталів, людей i техніки, вони значною мірою сприяють економічному зростанню і розвитку.

Проте їх економічна міць стає джерелом прихованих конфліктів з тими державами, на території яких здійснюється їх діяльність. По суті ТНК у все більшій мірі визначають міжнародну політику.

Спонукальними мотивами глобалізації бізнесу у фінансово-кредитній сфері $\epsilon$ зменшення ставок податків і митних зборів, можливість пролонгації терміну сплати податків, отримання дозволу на прискорену амортизацію, вільне переміщення або повернення прибутку на капітал та базової суми зовнішньої позики. Кошти, зекономлені на податках, надають ТНК фінансову мобільність, необхідну, зокрема, для високорентабельних зарубіжних проектів.

Третина світової торгівлі являє собою внутріфірмові операції ТНК, тобто перевезення товарів з підприємства, що належить ТНК в одній країні, на її ж підприємство в іншій [16].

Звідси й яскраво виражена тенденція посилення впливу транснаціональних корпорацій на світові процеси й безпосередньо пов'язана 3 нею економічна глобалізація світу. Хоча діяльність ТНК викликає чимало суперечок, по ряду пунктів думки різних дослідників і аналітиків збігаються. Практично загальновизнано, що: 
збільшується кількість фірм, діяльність яких виходить за межі національних кордонів (фактично будь-яка велика компанія сьогодні так чи інакше працює за межами національних рамок); стають все більш значимими обсяги діяльності ТНК, розширюється їхня сфера, охоплюючи не тільки продаж товарів, але й сервісних послуг;

$$
\text { діяльність багатьох }
$$

THK пов'язана 3 новими комунікаційними та інформаційними технологіями;

- активність більшості ТНК географічно акумулюється в розвинених або нових індустріальних країнах і значно менше - у нне дуже розвинених державах;

- якщо первісна більшість ТНК базувалася в США, то сьогодні ситуація дещо змінилася - сукупний акціонерний капітал, що належить іноземним громадянам у США, більший від капіталу, що належить американцям за межами їхніх кордонів;

все менш очевидною стає національна прив'язка транснаціональних корпорацій [2].

Іноді вважають, що ТНК є провідниками національного бізнесу за межами своєї країни. Однак, на думку К. Брауна, ТНК зацікавлені, в першу чергу, в одержанні прибутку, тому в більшості випадків, насамперед, виходять із цих міркувань, а не з необхідності підтримки національної могутності [7].

Ці особливості ТНК багато в чому визначають сучасну економічну ситуацію в світі, а отже, і його політичний розвиток. Так, ті ж США виявляються не в змозі контролювати діяльність ТНК. 3 погляду світової політики, це ще один доказ того, що роль держав змінилася кардинальним чином i змушує їх шукати нові методи впливу на великий бізнес. ТНК як нові економічні суб'єкти перетворились на одну з основних рушійних сил глобалізації, і це змушує багатьох аналітиків засумніватися в поширеній думці, начебто в основі глобалізації лежать вільний ринок і вільна конкуренція. Ринок, звичайно, відіграє істотну роль. Але це далеко не вільний ринок. Існує, хай і не в такій очевидній формі, як у перші післявоєнні десятиліття, вагоме державне регулювання експорту й імпорту товарів і капіталів. Як відомо, деякі держави та міжнародні об'єднання, виходячи з політичних міркувань, можуть вводити економічні санкції або обмеження щодо інших країн та регіонів.

Конкуренція ТНК носить скоріше олігополістичний характер, ніж вільний. Це означає, що взаємовідносини суб'єктів, які визначають глобальну гру на ринках товарів і капіталів, не тільки конкурентні в первісному значенні цього слова (боротьба за клієнта шляхом цінової або якісної привабливості товару), але й включають широку практику взаємних домовленостей, угод про розподіл зон впливу й т.ін.

Розширення торгівлі між країнами в другій половині XX ст. означало не тільки поширення ринкових відносин капіталістичного типу на всі куточки світового простору. Воно мало також інтегруючий ефект, тому що у все більшій мірі базувалось на внутрівиробничому поділі праці. Це особливо помітно в рамках внутрікорпораційного торговельного обміну. Великі ТНК поєднують свої торговельні операції з вивезенням капіталу, створюють на території інших держав виробництва, аналогічні тим, якими вони займаються у своїх країнах (країнах походження), або ж виготовляють окремі комплектуючі деталі й вузли для складної кінцевої продукції, що випускається ними в одній із країн розміщення виробництва.

Цей процес, з одного боку, говорить про раціональність і ефективність глобалізації, з іншого веде до конкурентної боротьбі як між корпораціями, так і між державами. Боротьба не тільки загострюється, але й набирає все більш руйнівного характеру. Багато в чому це прямий наслідок політики лібералізації і приватизації, що проводилась в останні десятиліття XX ст.

В результаті цього на сьогодні величезне значення набрав той факт, що зараз визначаються структури й розстановка сил на тривалий час, і кожна ТНК прагне скоріше захопити вигідніші й впливовіші плацдарми, при цьому час- 
то-густо нехнуючи інтересами окремих країн та їх держав. В цьому сенсі останні «кольорові» революції та регіональні конфлікти набувають дещо іншого, ніж політичне, забарвлення.

Ліберальна модель економічного розвитку світу у XXI ст. продемонструвала два суттєві відхилення від теоретичної неокласичної схеми. 3 одного боку, концентрація могутніх ТНК у промислово розвинених країнах забезпечувала їхнє безроздільне панування на ринках усіх інших регіонів світу. 3 іншого боку, 3 трьох основних ринків (товарів, капіталів, робочої сили) лібералізованими виявились тільки перші два, оскільки на переміщення робочої сили розвинені держави наклали жорстокі обмеження.

Наприкінці 90-х рp. ХХ ст. із критикою такої політики почали виступати багато політичних діячів i вчених, які раніше не висловлювалися проти концепцій неолібералізму. Відомий фахівець із питань міжнародної торгівлі Дж. Бхагвати опублікував статтю з гострою критикою всієї концепції дерегулювання фінансової сфери [6]. Дж. Стігліц обвинувачував МВФ за надмірну жорсткість, 3 якою він нав'язував країнам основні вимоги Вашингтонського консенсусу: монетаристську політику, дерегулювання економіки, скорочення господарських функцій держави, політику приватизації [15]. Аналогічні думки розвивав Дж.Сакс [14]. П. Кругман попереджав про можливу кризу в реальній економіці й небезпечному ослабленні всього інструментарію антикризової політики [11]. Biдомий дослідник неолібералізму К. Омае вказав на похмурі перспективи, що намічаються в результаті глобалізації [12].

У відповідь апологети неолібералізму почали розробляти рекомендації з удосконалення неоліберальної глобалізації шляхом урахування соціальних аспектів розвитку й потреб країн, що розвиваються [13]. Деякі автори сподіваються на можливості саморегулювання нових центрів світогосподарських рішень шляхом прийняття кодексів поведінки транснаціональними корпораціями або асоціаціями підприємців [8]. Інші вважають, що головні зусилля повинні бути спрямовані на те, щоб за допомогою податків і інших економічних та адміністративних важелів покласти на ТНК можливо більшу частину тих витрат, які їм вдається поки що уникати [9].

Національні держави, навіть враховуючи зменшення їх ролі і впливу, залишаються важливими діючими особами у сучасному світі. Проте, окрім ТНК, зростає і число інших акторів світового порядку:

- міжнародні інститути й організації формують норми і домагаються своїх цілей. 3 більшою або меншою мірою добровільності уряди поступаються їм частиною державного суверенітету. Варто виникнути якомусь режиму (наприклад, Європейському Союзу або СОТ), як він знаходить власну динаміку;

мережі суспільних акторів (неурядових організацій) охоплюють земну кулю й перетворюються на політичну силу, 3 якою доводиться серйозно рахуватись;

- гібридні утворення (державно-приватно-суспільні групи, або актори третього сектора) відіграють зростаючу, опосередковану роль і застосовують нові форми управління.

Можна констатувати, що на міжнародному рівні ми стикаємося із зростаючим розмаїттям дійових осіб. Сформована після підписання в 1648 г. Вестфальського миру система, в якій головну роль відігравали держави, сьогодні вже пішла в минуле. Формування ж нової ефективної системи, що поєднує в собі ієрархію організацій і координацію їх діяльності, утруднене не тільки через множинність акторів, але й їхньої різної природи. Насамперед, це стосується самої суті їхьої легітимації: одні здобувають свій мандат, проходячи процедуру виборів, інші ні, та й часовий відрізок їхньої легітимації досить різний.

Аналіз сучасної міжнародної практики дозволяє визначити три типи суспільних систем, у яких держави можуть виступати в ролі суб'єктів господарювання за межами національних кордонів. Ці типи різняться тим, які елементи культури є для них визначальними. При переважно раціональному підході (плюралістичний варіант) особливо важливим $е$ уникнення надмірного втручання бюро- 
кратичного апарату у справи громадян, яким повинні бути гарантовані свобода, життя й приватна власність. У такому разі міжнародне суспільство в ідеалі уявляється як суспільство держав, що домовилися про створення єдиного економічного простору з мінімумом обмежень i спільно долають негативні ринкові впливи ззовні. Економічно лідируюча в такому міжнародному суспільстві держава продукує його культурні норми, що укладаються в загальний ліберальний контекст. Якщо міжнародна відповідальність держави вступає в протиріччя 3 його національною відповідальністю, вибір робиться на користь останньої.

Корпоративний (європейський) варіант відводить державі більш активну господарську роль, що грунтується на сприйнятті соціальних відносин як основи економічного обміну. Це робить допустимим i необхідним обмеження нормативними засобами вільної гри ринкових сил. Іншими словами, соціальні норми європейцям важливіші від егоїстичних особистих інтересів, які випливають із суспільних і носять стосовно них підлеглий характер. I хоча вищим орієнтиром для держави в його господарській діяльності виявляються не ринок, як такий, а соціальний мир і якість життя, що досягаються 3 його допомогою, між представниками держави й бізнесу складаються відносини взаємної довіри і культура співробітництва в господарських питаннях, причому кожний привносить у них специфічний ресурс, який має. Інститути Європейського Союзу, у першу чергу Європейська комісія, виступають при цьому в якості посередників, порадників, експертів, «мудреців», які беруть участь у процедурах суспільного узгодження, а національні бюрократи (з боку держав) і асоціації підприємців та працівників (з боку суспільства) підтримують їх.

Тут необхідно особливо підкреслити специфічну роль функціонально спеціалізованої євробюрократії - основного європейського «інтегратора», стурбованого, передусім, керованістю й передбачуваністю процесів у сфері господарської діяльності незалежно від національних кордонів. Бюрократи віддають перева- гу компромісу, входять у дріб'язкові деталі кожного питання, рідко йдуть на загострення конфлікту 3 опонентами. Виграш від інтеграції досягається в результаті поступового й скрупульозного вироблення всіма їі учасниками загальної культури. Вони встановлюють усе більше число спільних норм, що стають частиною їхньої ідентичності, а та у свою чергу народжує колективну зацікавленість у дотриманні норм як кінцевої мети регіональної взаємодії. Показово, до речі, що в США практично не було й немає технократичної і політично ангажованої бюрократії європейського типу.

Таким чином, при ціннісному підході (корпоративний варіант) метою є захист способу життя, спільного для членів міжнародного співтовариства. Саме по тому, наскільки успішно воно цей спосіб життя захищає, оцінюється й ефективність об'єднання. В інтеграційному контексті міжнародної відповідальності держави віддається пріоритет перед національною.

На сьогодні, як відзначають деякі аналітики, іде формування третього, поряд із плюралістичним і корпоративістським типом суспільства - мережної моделі. В ЄС сьогодні спостерігається відхід від традиційної державницької моделі управління, в якій воно зводиться до того, чим займаються національні уряди, що володіють величезними ресурсами. У мережному варіанті взаємодіють автономні соціальні актори, а інтеграційні інститути 3 командної інстанції перетворюються на партнера й посередника. Відповідальність європейських держав як членів міжнародного співтовариства в складі ЄС оцінюється не стільки мірою їх лояльності власній нації, скільки вірністю європейським цінностям. На відміну від плюралістичного варіанта нормативна влада в корпоративному варіанті коштує вище, ніж влада виконавча. Утворюючи міжнародне суспільство, держави, що входять до Свропейського Союзу, спільно виробляють і формулюють загальні норми й моральні критерії політичної поведінки. Уступаючи якісь суверенні права ЄС, вони разом з тим зміцнюють свою інституціональну автономію від національного суспільства. 
Отже, держави, змінюючи свої функції й передаючи їх частково іншим акторам, тим самим віддають їм почасти й управління. Відзначимо, що управлінський ресурс сучасних держав-учасників світової політичної системи досить різноманітний. Це можуть бути політичний голос держави при прийнятті рішень $\mathrm{OOH}$, фінансові можливості ТНК або довіра суспільної думки до певних неурядових організацій. Ресурси такого роду складно порівнювати, а отже, наслідки їхніх різних комбінацій важко прораховуються. При цьому держави зберігають за собою монополію як суб'єктів міжнародного права. Важливий момент полягає в тому, що складні глобальні управлінські зв'язки світу не є ієрархічними, як всередині держави (хоча й там жорстка ієрархія розмивається). У той же час вони вже й не анархічні, про що пишуть Дж. Розенау, Д. Месснер та багато інших авторів [3]. Сучасна політика заснована на виробленні колективних рішень через безліч узгоджень різного рівНя.

Для розуміння складної системи глобального управління евристичним може виявитися підхід українського дослідника В М. Сергеєва, який бачить у демократії й, отже, у демократичному управлінні узгодження інтересів різних груп шляхом переговорів. На глобальному рівні це можуть бути багатобічні міждержавні форми, що відкривають можливості для колективного управління взаємозалежністю [5].

Це можуть бути й спільні зустрічі представників держав і недержавних акторів. Одним із таких прикладів може слугувати Конференція по стійкому розвитку, що відбулася в Йоганнесбурзі в серпні 2002 р., яка продемонструвала ідеї партнерської взаємодії урядів, бізнесу й НПО при вирішенні глобальних проблем. Однак якщо координацію дій різних акторів удається якось налагоди- ти, то виконавчі функції по їх реалізації поки що погано реалізуються навіть у тих випадках, коли шляхом спільних зусиль згоди все-таки досягають. Один із таких прикладів - складності, пов'язані з виконанням Кіотського протоколу [1].

Висновки. Враховуючи збільшення ролі ТНК як у світовій економіці, так і світовій політичній сфері можна чітко відзначити наступні параметри глобального управління:

- участь різних акторів;

- відсутність ієрархічності зв'язків між ними;

- множинність форм і методів взаємодіï;

- використання переговорів для погоджень.

Одним із ключових лишається питання про подальші шляхи розподілу управлінських повноважень між акторами в політичній структурі світу, економічною основою якої є транснаціональний бізнес.

Множинність учасників сучасних світових процесів, активне підключення нових (нетрадиційних) акторів до міжнародних відносин має багато наслідків. Один 3 них полягає в тому, що держави «діляться» частиною своїх владних повноважень, «передаючи» їх іншим учасникам. Таким чином, стирається грань між зовнішньою і внутрішньою політикою.

Для України ця ситуація має не тільки і не стільки теоретичне значення, скільки є реальним сьогоденням внутрішньої і зовнішньої політки. Різні підходи США та СС по відношенню до ролі національної держави у глобалізованому світі створюють додаткові складності для української держави щодо подолання соціально-економічної та політичної кризи в країні, що виникла в результаті конкурентної боротьби транснаціональних бізнесових утворень та великих держав, що захищають свої глобальні інтереси.

\section{СПИСОК АІТЕРАТУРИ:}

1. Йоханнесбургская встреча на высшем уровне 2002 года - Режим доступу: http://www. un.org/ru/events/pastevents/wssd.shtml

2. Конина Н. Ю. Конкурентоспособность фирмы в глобальном мире / Н. Ю. Конина. - М.: Проспект, 2012.

3. Месснер Д. Архитектура мирового порядка: стратегии решения глобальных проблем // 
Internationale Politik, 1998. Вып. 11, ноябрь (на рус. языке).

4. Неклесса A. Рax оесоnomicana: геоэкономическая система мироустройства // Глобальное сообщество: изменение социальной парадигмы. М., 1999.

5. Сергеев В.М. Демократия как переговорный процесс. М., 1999.

6. Bhagwati J. The Capital Myth // Foreign Affairs. May/June 1998.

7. Brown Ch. Understanding International Relations. N.Y., 2001.

8. Bruyn S.T. A Civil Economy. Transforming the Market in the Twenty-First Century. Ann Arbor, 2000.

9. Hawkens P., Lovins A. Natural Capitalism. Creating the Next Industrial Revolution. 2000.

10. Hirst P., Tompson G. Globalization and the Future of the Nation State // Economy and Society. L., 1995. Vol.24. №3.

11. Krugman P. The Return of Depression Economics. N.Y., 1999.

12. Ohmae K. The Invisible Continent. Strategic Imperatives of the New Economy. N.Y., 2000.

13. Rodrik D. The New Global Economy and Developing Countries: Making Openness Work. Wash., 1999.

14. Sachs J. Global Capitalism: Making it Work // The Economist, 12.09.1998.

15. Stiglitz J. More Instruments and Broader Goals: Moving Towards the Post-Washington Consensus. WIDER Paper. Helsinki, 1998.

16. World Investment Report 2012 / UNCTAD / United Nations, New York and Geneva, 2012.

\section{REFERENCES:}

1. Yohannesburgskaya vstrecha na vyisshem urovne 2002 goda (Johannesburg Summit 2002). Access: http://www.un.org/ru/events/pastevents/wssd.shtml

2. Konina N. Yu. Konkurentosposobnost firmyi v globalnom mire (The competitiveness of firms in the global world). - M.: Prospekt, 2012.

3. Messner D. Arhitektura mirovogo poryadka: strategii resheniya globalnyih problem (The architecture of the world order: a strategy to address global challenges). Internationale Politik, 1998. Vyip. 11, noyabr (na rus. yazyike).

4. Neklessa A. Pax oeconomicana: geoekonomicheskaya syistema miroustroystva (Pax oeconomicana: Drive system geo-economic world order). Globalnoe soobschestvo: izmenenie sotsialnoy paradigmyi. M., 1999.

5. Sergeev V.M. Demokratiya kak peregovornyiy protsess (Democracy as the negotiation process). M., 1999.

6. Bhagwati J. The Capital Myth // Foreign Affairs. May/June 1998.

7. Brown Ch. Understanding International Relations. N.Y., 2001.

8. Bruyn S.T. A Civil Economy. Transforming the Market in the Twenty-First Century. Ann Arbor, 2000.

9. Hawkens P., Lovins A. Natural Capitalism. Creating the Next Industrial Revolution. 2000.

10. Hirst P., Tompson G. Globalization and the Future of the Nation State // Economy and Society. L., 1995. Vol.24. №3.

11. Krugman P. The Return of Depression Economics. N.Y., 1999.

12. Ohmae K. The Invisible Continent. Strategic Imperatives of the New Economy. N.Y., 2000.

13. Rodrik D. The New Global Economy and Developing Countries: Making Openness Work. Wash., 1999.

14. Sachs J. Global Capitalism: Making it Work // The Economist, 12.09.1998.

15. Stiglitz J. More Instruments and Broader Goals: Moving Towards the Post-Washington Consensus. WIDER Paper. Helsinki, 1998.

16. World Investment Report 2012 / UNCTAD / United Nations, New York and Geneva, 2012.

Квітка Сергій Андрійович - кандидат філософських наук, доцент

Дніпропетровський регіональний інститут державного управління Національної академії державного управління при Президентові України

Адреса: 49044, м. Дніпропетровськ, вул. Гоголя, 29

E-mail:skvitka@i.ua

Kvitka Serhii Andriiovych - PhD in philosophy, associate professor

Dnepropetrovsk regional institute of public administration, the National academy of public administration, office of the President of Ukraine

Address: 29, Gogol Str., Dnipropetrovsk, 49044, Ukraine

E-mail:skvitka@i.ua 